\title{
Ascorbic Acid Induced Atrazine Degradation
}

\author{
Xiaojing Hou, Xiaopeng Huang, Zhihui Ai ${ }^{*}$ Jincai Zhao, and Lizhi Zhang ${ }^{*}$
}

Key Laboratory of Pesticide \& Chemical Biology of Ministry of Education, Institute of Environmental Chemistry, College of Chemistry, Central China Normal University, Wuhan 430079, P. R. China

*Corresponding author. Phone/fax: +86-27-6786 7535.

Email address: jennifer.ai@mail.ccnu.edu.cn (Z. Ai); zhanglz@mail.ccnu.edu.cn (L. Zhang)

\begin{abstract}
In this study, we systematically investigated the degradation efficiency and the degradation mechanism of atrazine in the presence of ascorbic acid at different $\mathrm{pH}$ values. Although atrazine could be degraded by ascorbic acid in a wide $\mathrm{pH}$ range from 4 to 12 , its degradation under either acidic $(\mathrm{pH} \leq 4)$ or alkaline $(\mathrm{pH} \geq 12)$ condition was more efficient than under neutral condition $(\mathrm{pH}$ =7). This $\mathrm{pH}$ dependent atrazine degradation was related to the reactive characteristic of atrazine and the reductive activity of ascorbic acid. The ascorbic acid induced atrazine degradation pathways at different $\mathrm{pH}$ were investigated by comparing the atrazine degradation intermediates with liquid chromatography-mass spectrometry, high performance liquid chromatography and ion chromatography. It was found that more products were detected in presence of ascorbic acid at alkaline condition. The appearance of chloride ions confirmed the dechlorination of atrazine by ascorbic acid in the absence of molecular oxygen, while its dechlorination efficiency reached highest at $\mathrm{pH}$ 12. These results can shed light on the application of AA for the organic pollutant remediation.
\end{abstract}

Keywords Ascorbic acid; Atrazine; Degradation; Liquid chromatography-mass spectrometry; Pollutant remediation 


\section{Introduction}

Atrazine (2-chloro-4-ethylamino-6-isopropylamino-s-triazine) is widely used to kill pre- and postemergence broadleaf and grassy weeds, and gradually causes a worldwide environmental pollution [1-4], as well as exhibits identified reproductive and developmental abnormalities in rodent models [5-8]. Moreover, the high production (70 000 - 90000 tons annually), moderate aqueous solubility, high persistence in water (the half-life of about 100 days), and high mobility of atrazine might further worsen its adverse health effects [9-12]. Unfortunately, the atrazine concentration in groundwater has been frequently found to be higher than the maximum permissible level $\left(0.1 \mu \mathrm{g} \mathrm{L}^{-1}\right)$ for drinking water set by the European Community (EC) [13], while the United States Environmental Protection Agency (USEPA) set its drinking water limit at $3 \mu \mathrm{g} \mathrm{L}^{-1}$ [14]. Therefore, it is obligatory to remove atrazine from water for the safety of human drinking.

Unfortunately, conventional water treatment processes such as coagulation/flocculation, filtration, and chlorination could not effectively remove atrazine from water [15-17]. Although physical treatments based on membrane technology, activated carbon adsorption, advanced oxidation processes (AOPs), biodegradation, and zerovalent metal reduction are efficient for the removal of atrazine from water [18-24], they are very expensive for the contaminated water remediation. Given that the widespread occurrence of atrazine pollution, it is of great importance to develop effective and inexpensive treatment technologies for the atrazine removal from contaminated water.

Ascorbic acid $\left(\mathrm{C}_{6} \mathrm{H}_{8} \mathrm{O}_{6}, \mathrm{H}_{2} \mathrm{~A}\right)$, also known as vitamin $\mathrm{C}$, is used as broadly as possible to include cosmetic, pharmaceutical and agricultural fields because of its biologic antioxidant property. It is a dibasic acid and can release protons in two steps in aqueous solution to form ascorbic anion $\left(\mathrm{C}_{6} \mathrm{H}_{7} \mathrm{O}_{6}^{-}, \mathrm{HA}^{-}\right)$with a pK $\mathrm{a}_{1}$ value of $4.25(E q .1)$ and dianionic ascorbic acid $\left(\mathrm{C}_{6} \mathrm{H}_{6} \mathrm{O}_{6}{ }^{2-}, \mathrm{A}^{2-}\right)$ with a $\mathrm{pK}_{\mathrm{a} 2}$ value of 11.79 (Eq. 2) [25-27]. Meanwhile, AA (the general name for $\mathrm{H}_{2} \mathrm{~A}, \mathrm{HA}^{-}$and $\mathrm{A}^{2-}$ ) can also serve as an ecofriendly reductant, being fully oxidized in two one-electron step or one 
two-electron step both in acid (Eqs. 3 - 6) and alkaline aqueous solutions (Eqs. 7 - 9) [28-29]. In addition, AA is ubiquitous in the plants and might thus be applied for environment pollution remediation. Moreover, the rate constants of AA oxidation via one-electron step under acid, neutral, and alkaline conditions are $2 \times 10^{3} \mathrm{M}^{-1} \mathrm{~s}^{-1}, 1 \times 10^{5} \mathrm{M}^{-1} \mathrm{~s}^{-1}$, and $2 \times 10^{5} \mathrm{M}^{-1} \mathrm{~s}^{-1}$, respectively, suggesting that the oxidation of AA is strongly dependent on the $\mathrm{pH}$ values and $\mathrm{AA}$ is more likely to be oxidized under alkaline condition than acid condition.

$$
\begin{array}{ll}
\mathrm{C}_{6} \mathrm{H}_{8} \mathrm{O}_{6} \rightarrow \mathrm{C}_{6} \mathrm{H}_{7} \mathrm{O}_{6}{ }^{-}+\mathrm{H}^{+} & \mathrm{pK}_{\mathrm{a} 1}=4.25 \\
\mathrm{C}_{6} \mathrm{H}_{7} \mathrm{O}_{6}{ }^{-} \rightarrow \mathrm{C}_{6} \mathrm{H}_{6} \mathrm{O}_{6}{ }^{2-}+\mathrm{H}^{+} & \mathrm{pK}_{\mathrm{a} 2}=11.79 \\
\mathrm{C}_{6} \mathrm{H}_{8} \mathrm{O}_{6} \rightarrow \cdot \mathrm{C}_{6} \mathrm{H}_{7} \mathrm{O}_{6}+\mathrm{e}^{-}+\mathrm{H}^{+} & k_{1}=2 \times 10^{3} \mathrm{M}^{-1} \mathrm{~s}^{-1} \\
\cdot \mathrm{C}_{6} \mathrm{H}_{7} \mathrm{O}_{6} \rightarrow \mathrm{C}_{6} \mathrm{H}_{6} \mathrm{O}_{6}+\mathrm{e}^{-}+\mathrm{H}^{+} & \\
\mathrm{C}_{6} \mathrm{H}_{8} \mathrm{O}_{6} \rightarrow \mathrm{C}_{6} \mathrm{H}_{6} \mathrm{O}_{6}+2 \mathrm{e}^{-}+2 \mathrm{H}^{+} & \\
\mathrm{C}_{6} \mathrm{H}_{7} \mathrm{O}_{6}{ }^{-} \rightarrow \cdot \mathrm{C}_{6} \mathrm{H}_{6} \mathrm{O}_{6}+\mathrm{e}^{-}+\mathrm{H}^{+} & k_{2}=1 \times 10^{5} \mathrm{M}^{-1} \mathrm{~s}^{-1} \\
\mathrm{C}_{6} \mathrm{H}_{6} \mathrm{O}_{6}{ }^{2-} \rightarrow \cdot \mathrm{C}_{6} \mathrm{H}_{6} \mathrm{O}_{6}{ }^{-}+\mathrm{e}^{-} & k_{3}=2 \times 10^{5} \mathrm{M}^{-1} \mathrm{~s}^{-1} \\
\cdot \mathrm{C}_{6} \mathrm{H}_{6} \mathrm{O}_{6}{ }^{-} \rightarrow \mathrm{C}_{6} \mathrm{H}_{6} \mathrm{O}_{6}+\mathrm{e}^{-} & \\
\mathrm{C}_{6} \mathrm{H}_{6} \mathrm{O}_{6}{ }^{2-} \rightarrow \mathrm{C}_{6} \mathrm{H}_{6} \mathrm{O}_{6}+2 \mathrm{e}^{-} &
\end{array}
$$

It is well known that the redox activity of $\mathrm{AA}$ is strongly dependent on the $\mathrm{pH}$ value. For example, Ogren and Saiprakash et al. demonstrated that methylene blue could be reduced by AA under strongly acidic conditions and also studied the kinetic process systematically [30-31]. Hsieh and his co-workers reported that $\mathrm{Fe}(\mathrm{III})$ could be stably reduced to $\mathrm{Fe}(\mathrm{II})$ by AA in the $\mathrm{pH}$ range of $4-6$, but the $\mathrm{Fe}(\mathrm{III})$ reduction rate decreased markedly at $\mathrm{pH}>6$ [32]. Furthermore, some researchers suggested that dianionic ascorbic acid $\left(\mathrm{C}_{6} \mathrm{H}_{6} \mathrm{O}_{6}{ }^{2-}\right)$ was the most important reductant for iron or iron complex under neutral $\mathrm{pH}$ values because the standard redox potential $(0.019 \mathrm{~V})$ of $\cdot \mathrm{C}_{6} \mathrm{H}_{6} \mathrm{O}_{6}{ }^{-} / \mathrm{C}_{6} \mathrm{H}_{6} \mathrm{O}_{6}{ }^{2-}$ was lower than that $(0.282 \mathrm{~V})$ of $\cdot \mathrm{C}_{6} \mathrm{H}_{6} \mathrm{O}_{6}{ }^{-} / \mathrm{C}_{6} \mathrm{H}_{7} \mathrm{O}_{6}{ }^{-}$[33-35]. Recently, Liang's group reported that $\mathrm{AA}$ could reduce carbon tetrachloride at $\mathrm{pH} 13$ [36], reduce mer-[Ru $\left.{ }^{\mathrm{III}}(\mathrm{pic})_{3}\right]$ 
complex $\left(\mathrm{pic}^{-}=\right.$picolinato) to produce a red ruthenium(II) species in a wide $\mathrm{pH}$ range of $1.0-7.4$ [28]. In addition, they also confirmed that alkaline ascorbic acid exhibited more effective activity on reductive degradation of nitrobenzene [37]. In these previous studies, the AA concentrations were in the range of 1 to $50 \mathrm{mmol} \mathrm{L}^{-1}$.

In this study, we demonstrate that ascorbic acid of relatively low concentration $\left(1 \mathrm{mmol} \mathrm{L}^{-1}\right)$ can induce the degradation of atrazine in aqueous solution. Especially, we systematically investigate the degradation efficiency and degradation mechanism of atrazine in the presence of ascorbic acid at different $\mathrm{pH}$ values. Meanwhile, we analyze the atrazine degradation intermediates with different techniques and also propose a kinetic model to discuss the atrazine degradation mechanism.

\section{Experimental Section}

\subsection{Chemicals and Materials.}

Atrazine was purchased from Sigma-Aldrich. Ascorbic acid, sulfuric acid and sodium hydroxide were all of analytical grade and purchased from National Medicines Corporation Ltd. China. Acetonitrile, acetone, and formic acid were of HPLC grade and obtained from Merk KGaA. All chemicals were used as received without further purification. Deionized water was used throughout the experiments. $1 \mathrm{~mol} / \mathrm{L}$ of AA stock solution was prepared by directly dissolving AA in deoxygenized and deionized water. The atrazine solution $\left(2 \mathrm{mg} \mathrm{L}^{-1}\right)$ was prepared by adding the required amount of pure atrazine in water and stirred for more than $24 \mathrm{~h}$ in a $1 \mathrm{~L}$ borosilicate reservoir at about $25{ }^{\circ} \mathrm{C}$. $\mathrm{NaOH}$ and $\mathrm{H}_{2} \mathrm{SO}_{4}$ solutions were used to adjust the $\mathrm{pH}$ value of the solutions. All the stock solutions were freshly prepared before use.

\subsection{Degradation Procedures.}

All the experiments were performed in $100 \mathrm{~mL}$ conical flasks under Ar atmosphere at room temperature $\left(25 \pm 5{ }^{\circ} \mathrm{C}\right)$. Typically, the atrazine solutions were deoxygenized by pumping 
high-purity argon gas into for $30 \mathrm{~min}$ at a rate of $1.5 \mathrm{~L} \mathrm{~min}^{-1}$. Different dosages of $1 \mathrm{~mol} \mathrm{~L}^{-1} \mathrm{AA}$ solution were then added into $50 \mathrm{~mL}$ of the deoxygenized atrazine solutions $\left(2 \mathrm{mg} \mathrm{L}^{-1}\right)$ at $\mathrm{pH}$ of 4,7 , and 12. Being sealed with the rubber stoppers, conical flasks were pumped with high-purity argon gas for another $30 \mathrm{~min}$, along with needles being inserted in the rubber stoppers for gas escaping. All the reactions were carried out in darkness at $25^{\circ} \mathrm{C}$. Control experiments in the absence of AA were also carried out in parallel for comparison. All the experiments were conducted in triplicate and averaged data and error ranges with one standard deviation were presented.

\subsection{Analytical Methods.}

The concentration of atrazine was monitored by high performance liquid chromatography (HPLC, Ultimate 3000, Thermo, USA) with an Agilent TC-C18 reverse phase column $(150 \mathrm{~mm} \times 4.6 \mathrm{~mm}, 5$ $\mu \mathrm{m})$. The injection volume was $10 \mu \mathrm{L}$, the eluent was $\mathrm{H}_{2} \mathrm{O}$ : acetonitrile $=50 \%: 50 \%$, the flow rate was $1 \mathrm{~mL} / \mathrm{min}$. The UV detector was set at $220 \mathrm{~nm}$ and the temperature of column was maintained at $30{ }^{\circ} \mathrm{C}$.

AA concentration was measured by a modified previously described method [38]. The chlorine ions were detected by using an ion chromatograph (IC, Dionex ICS-900, Thermo, USA) equipped with an AS23 column. The possible degradation intermediates of atrazine and AA were identified by liquid chromatography-mass spectrometry (LC-MS, TSQ Quantum MAX, Thermo, USA) with a Hypersil Gold C18 column of $150 \mathrm{~mm} \times 2.1 \mathrm{~mm}$ and $2 \mu \mathrm{m}$ particle size, $300 \AA$. Typical procedure is in the Supporting Information.

The $\mathrm{pH}$ was measured using a $\mathrm{pH}$ meter (Thermo Orion $720 \mathrm{~A}+$ ) equipped with a Mettler Toledo Inlab $437 \mathrm{pH}$ combination electrode. The oxidation-reduction potentials of solutions were measured by a pH meter (Thermo Orion $720 \mathrm{~A}+$ ) equipped with a redox combination electrode.

\subsection{Theoretical Calculations.}

All the calculations were performed by using the Gaussian 09 package [39]. The geometry 
optimization of all the protolytic forms $\left(\mathrm{C}_{6} \mathrm{H}_{8} \mathrm{O}_{6}, \mathrm{C}_{6} \mathrm{H}_{7} \mathrm{O}_{6}{ }^{-}\right.$, and $\left.\mathrm{C}_{6} \mathrm{H}_{6} \mathrm{O}_{6}{ }^{2-}\right)$ of ascorbic acid were performed by the M062X functional with the $6-311 G^{* *}$ basis sets. The Gibbs free energy changes and the ionization energy calculation for atrazine and all the protolytic forms of ascorbic acid were calculated using the M062X functional with the TZVP basis sets [40]. The optimization was repeated in solvent (water) described by the integral equation formalism polarizable continuum model (IEFPCM) model [41].

\section{Results and Discussion}

\subsection{The degradation of atrazine in the presence of ascorbic acid.}

Figure 1 shows the effect of AA concentrations on the degradation efficiency of atrazine. The initial $\mathrm{pH}$ values of different AA solutions $\left(0.5,1.0\right.$ and $\left.2.0 \mathrm{mmol} \mathrm{L}^{-1}\right)$ were about 4 . We found that the atrazine degradation was not obvious in the absence of $\mathrm{AA}$ at $\mathrm{pH} 4$, and only $9 \%$ of atrazine was degraded within 20 days, accompanying with degradation first-order rate constant of 0.005 day $^{-1}$. The apparent atrazine degradation rate constants in the presence of $0.5,1.0$ and $2.0 \mathrm{mmol} \mathrm{L}^{-1}$ of AA were $0.016,0.076$, and $0.116 \mathrm{day}^{-1}$, respectively. Obviously, the degradation efficiency of atrazine increased along with increasing the AA concentration. As the degradation percentage (80\%) of atrazine within 20 days at $1.0 \mathrm{mmol} \mathrm{L}^{-1}$ of AA was close to that $(89 \%)$ at $2 \mathrm{mmol} \mathrm{L}^{-1}$ of AA, 1.0 mmol $\mathrm{L}^{-1}$ was thus chosen as the optimal AA concentration in this study. During the AA induced atrazine degradation, the AA amount was much excess and the AA had low consumption (Figure S1 in the Supporting Information), accounting for the pseudo-first-order kinetics of the atrazine degradation $\left(\mathrm{R}^{2}>0.9\right)$.

\subsection{The effect of pH on atrazine degradation in the presence of ascorbic acid}

Regarding that the $\mathrm{pH}$ value is crucial for the reducibility of AA, we further checked the effect of $\mathrm{pH}$ on the atrazine degradation by AA through comparing AA induced atrazine degradation at different $\mathrm{pH}$ values $\left(4,7\right.$ and 12) covering the $\mathrm{pK}_{\mathrm{a}}$ values of $\mathrm{AA}\left(\mathrm{pK}_{\mathrm{a} 1}=4.25\right.$ and $\left.\mathrm{pK}_{\mathrm{a} 2}=11.79\right)$. As 
shown in Figure 2, atrazine could be degraded in the presence of AA in a wide range of $\mathrm{pH}$ from 4 to 12 , and the degradation rate constants $\left(0.077-0.175\right.$ day $\left.^{-1}\right)$ of atrazine in the presence of AA were about $19-128$ times that $\left(0.00007-0.009\right.$ day $\left.^{-1}\right)$ in the absence of AA. Interestingly, 1.0 mmol $\mathrm{L}^{-1}$ of AA could induce $100 \%$ degradation of atrazine at $\mathrm{pH} 12$ within 10 days and the corresponding degradation rate $\left(0.175\right.$ day $\left.^{-1}\right)$ was 2.3 times that $\left(0.077\right.$ day $\left.^{-1}\right)$ at $\mathrm{pH} 4$ and 12.5 times that $\left(0.014\right.$ day $\left.^{-1}\right)$ at $\mathrm{pH} 7$, respectively. These comparisons suggested that AA could more efficiently induce the atrazine degradation under alkaline condition. We also monitored the $\mathrm{pH}$ variations during atrazine anaerobic degradation with $\mathrm{AA}$ at different initial $\mathrm{pH}$ values $(4,7$ and 12) and found that the $\mathrm{pH}$ values did not change obviously during reaction in different systems (Figure $\mathrm{S} 2$ in the Supporting Information), revealing that all the reaction $\mathrm{pH}$ values were approximately equal to the initial $\mathrm{pH}$ values of the systems.

\subsection{The atrazine degradation pathway in the presence of ascorbic acid.}

Ion chromatograph was further used to monitor the $\mathrm{Cl}^{-}$releasing after 35 days' degradation of atrazine in the presence of AA at different $\mathrm{pH}$ values (Figure 3). At $\mathrm{pH} 4$, the concentrations of $\mathrm{Cl}^{-}$

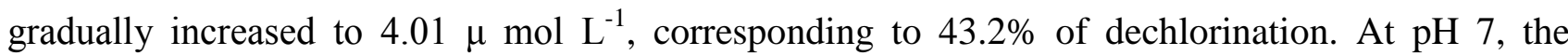
concentrations of $\mathrm{Cl}^{-}$only reached to $0.48 \mu \mathrm{mol} \mathrm{L}^{-1}$, indicative of $5.2 \%$ of dechlorination. At $\mathrm{pH} 12$, the concentrations of $\mathrm{Cl}^{-}$increased as high as $7.80 \mu \mathrm{mol} \mathrm{L} \mathrm{L}^{-1}$, corresponding to $84.1 \%$ of dechlorination. These results confirmed that atrazine could be degraded by AA, accompanying with significant dechlorination, especially at $\mathrm{pH} 12$.

All the intermediates of atrazine detected by chromatography-mass spectrometry LC-MS were identified by comparing the obtained fragments in the mass spectra with the data reported in the literatures (Figure S3 in the Supporting Information) [42-43]. Table S1 summarizes the structural formulas and molecular weights of the atrazine degradation intermediates detected by LC-MS at different $\mathrm{pH}$ values in the absence or presence of AA (Supporting Information). In the absence of 
AA, only the dealkylation product 2-chloro-4-amino-6-(isoproylamino)-s-triazine (CAIT) was detected at $\mathrm{pH} 4$ and the hydroxylation product 2-hydroxy-4-(isopropylamino)6-(ethylamino)-s-triazine (HIET) was detected at $\mathrm{pH} \mathrm{12,} \mathrm{while} \mathrm{no} \mathrm{intermediate} \mathrm{was} \mathrm{found} \mathrm{at} \mathrm{pH} 7$. In contrast, more intermediate products of atrazine were detected at all the $\mathrm{pH}$ values in the presence of AA. At $\mathrm{pH} \mathrm{4,} \mathrm{there} \mathrm{were} \mathrm{four} \mathrm{identified} \mathrm{intermediates,} \mathrm{including} \mathrm{hydroxylation} \mathrm{products} \mathrm{of} \mathrm{HIET}$ and dealkylation-hydroxylation products 2-hydroxy-4-(isopropylamino)-6-amino-s-triazine (HIAT), and dealkylation products of CAIT and 2-amino-4-chloro-6-(ethylamino)-s-triazine (CEAT). At pH 7 , there were two dealkylation products of CAIT and CEAT, and one hydroxylation product of HIET. Interestingly, nine intermediates were identified by LC-MS at pH 12. They were HIET, CAIT, CEAT, and dealkylation-hydroxylation products of HIAT, 2-hydroxyl-4-ethylamino-6-amino-1, 3, 5-triazine (HEAT) and 2-hydroxyl-4- ethylamino-6-methylamino-1, 3, 5-triazine (HEMT), as well as one reductive dechlorination product of 2-ethylamino-4-isopropylamino-1,3,5-trazine (EIAT). Furthermore, the appearance of reductive dechlorination product (EIAT) and reductive deaminization product 2-chloro-4-ethylamino-1, 3, 5-trazine (CET) suggested that the adverse environmental effects of atrazine might be greatly abated by the addition of AA. Previously, Stratton et al. found that these atrazine degradation intermediates of CAIT, CEAT, CAAT and HEMT were significantly less toxic than atrazine to the photosynthetic microorganisms [44], while it is widely accepted that the toxicity of atrazine could be reduced through the replacement of chlorine with hydroxyl group [45-48]. Thus, even these reductive degradation products of atrazine still act as endocrine disruptors, their quantity and toxicity are less than atrazine. Therefore, the appearance of dechlorination products of atrazine in presence of $\mathrm{AA}$ at all the $\mathrm{pH}$ values suggests that $\mathrm{AA}$ is promising for the atrazine contaminated water remediation.

High performance liquid chromatography (HPLC) was then used to detect typical degradation intermediates of atrazine in the presence of AA (Figure 4) and monitor their concentration changes 
(Figure 5). At $\mathrm{pH} \mathrm{4,} \mathrm{four} \mathrm{main} \mathrm{degradation} \mathrm{intermediates} \mathrm{of} \mathrm{CAIT,} \mathrm{CEAT,} \mathrm{HIET,} \mathrm{and} \mathrm{CAAT} \mathrm{were}$ also identified by HPLC. As shown in Figure 5a, the concentrations of CAIT and CEAT increased to 0.49 and $0.42 \mathrm{mg} / \mathrm{L}$, and then slowly decreased to $0.08\left([\mathrm{CAIT}] /[\text { atrazine }]_{0}=0.05\right)$ and $0.21 \mathrm{mg} / \mathrm{L}$ $\left([\mathrm{CEAT}] /[\text { atrazine }]_{0}=0.13\right)$, respectively. Meanwhile, the concentration of HIET improved slowly and reached $0.09 \mathrm{mg} / \mathrm{L}\left([\mathrm{HIET}] /[\text { atrazine }]_{0}=0.05\right)$. After 10 days, CAAT began to appear, along with the concentrations of CAIT and CEAT decreasing and the concentration of CAAT reaching 0.38 $\mathrm{mg} / \mathrm{L}\left([\mathrm{CAAT}] /[\text { atrazine }]_{0}=0.32\right)$. As there was $43.2 \%$ of dechlorination after 35 days, the molar ratio of CAIT, CEAT, CAAT and dechlorinated intermediates was $5: 13: 32: 43$, indicating that dechlorination was an important process of atrazine degradation besides dealkylation in the presence of $\mathrm{AA}$ at acidic $\mathrm{pH}$. At $\mathrm{pH} 7$, along with the degradation of atrazine, the concentrations of CAIT and CEAT improved to $0.41\left([\mathrm{CAIT}] /[\text { atrazine }]_{0}=0.22\right)$ and $0.22 \mathrm{mg} / \mathrm{L}\left([\mathrm{CEAT}] /[\text { atrazine }]_{0}=0.13\right)$, respectively (Figure 5b). The molar ratio of ACIT, CEAT and dechlorinated intermediates was 22 : $13: 5.2$, which suggested that the dealkylation was the main process during atrazine degradation in the presence of AA at neutral $\mathrm{pH}$. At $\mathrm{pH} \mathrm{12,} \mathrm{the} \mathrm{intermediates} \mathrm{of} \mathrm{atrazine} \mathrm{identified} \mathrm{by} \mathrm{HPLC}$ included HIET, CAIT, CEAT, and alkylation-hydroxylation product 2-hydroxyl-4,6-diamino-1, 3, 5-triazine (OAAT) in the presence of AA (Figure 5c). The concentration change trends of CAIT and CEAT were similar to those at $\mathrm{pH}$ 4. The concentrations of CAIT and CEAT first increased to 0.49 and $0.32 \mathrm{mg} / \mathrm{L}$, and then slowly decreased to $0.10\left([\mathrm{CAIT}] /[\text { atrazine }]_{0}=0.06\right)$ and $0.18 \mathrm{mg} / \mathrm{L}$ $\left([\mathrm{CEAT}] /[\text { atrazine }]_{0}=0.11\right)$, respectively. Meanwhile, the concentration of HIET also first increased to $0.77 \mathrm{mg} / \mathrm{L}$ and then decreased to $0.57 \mathrm{mg} / \mathrm{L}\left([\mathrm{HIET}] /[\text { atrazine }]_{0}=0.31\right)$ during the 35 days' degradation. Interestingly, atrazine was converted to OAAT at alkaline condition, as the OAAT concentration reached $0.46 \mathrm{mg} / \mathrm{L}\left([\mathrm{OAAT}] /[\text { atrazine }]_{0}=0.39\right)$ after 35 days. The molar ratio of CAIT, CEAT and dechlorinated intermediates was $6: 11: 82$. Therefore, we concluded that the dechlorination were the major processes during the atrazine degradation in the presence of AA at 
alkaline $\mathrm{pH}$. These above data confirmed the reductive degradation of atrazine. Meanwhile, atrazine preferred to convert into CAAT at acidic condition and OAAT at alkaline condition, respectively. On the basis of these intermediates, we proposed a possible atrazine degradation pathway in presence of AA at different $\mathrm{pH}$ values (Figure 6). In addition, the position of ascorbic acid in HPLC chromatograms was also analyzed (Figure S4 in the Supporting Information). The retention time of atrazine peak was 8.9 min in the HPLC, and the retention time of the peaks related to atrazine degradation products identified in this study were all more than 2 min in the HPLC. Nevertheless, the position of ascorbic acid peak was located at about $1.8 \mathrm{~min}$. Thus, ascorbic acid could not cause analytical interference with HPLC analysis used for atrazine determination.

\subsection{The possible mechanism of atrazine degradation in the presence of ascorbic acid.}

AA is a dibasic acid to exit in three protolytic forms $\left(\mathrm{C}_{6} \mathrm{H}_{8} \mathrm{O}_{6}, \mathrm{C}_{6} \mathrm{H}_{7} \mathrm{O}_{6}{ }^{-}\right.$and $\left.\mathrm{C}_{6} \mathrm{H}_{6} \mathrm{O}_{6}{ }^{2-}\right)$ in water (Figure S5 in the Supporting Information). As shown in Figure S5, there are two predominant species of $\mathrm{C}_{6} \mathrm{H}_{8} \mathrm{O}_{6}(51.2 \%)$ and $\mathrm{C}_{6} \mathrm{H}_{7} \mathrm{O}_{6}{ }^{-}(48.8 \%)$ at $\mathrm{pH} 4$, but only one major species $\mathrm{C}_{6} \mathrm{H}_{7} \mathrm{O}_{6}{ }^{-}$ (99.9\%) exists at $\mathrm{pH} 7$, as well as $\mathrm{C}_{6} \mathrm{H}_{6} \mathrm{O}_{6}{ }^{2-}$ (91.5\%) at $\mathrm{pH} 12$ (Table $\mathrm{S} 2$ in the Supporting Information). It is known that the reductive activity of ascorbic acid depends on the oxidation potential of its protolytic forms, which could be reflected by their vertical ionization potential (VIP) values [49]. Therefore, we calculated the VIP values of different protolytic AA by Gaussian 09 using M062X function. The VIP values of $\mathrm{C}_{6} \mathrm{H}_{8} \mathrm{O}_{6}, \mathrm{C}_{6} \mathrm{H}_{7} \mathrm{O}_{6}{ }^{-}$and $\mathrm{C}_{6} \mathrm{H}_{6} \mathrm{O}_{6}{ }^{2-}$ were calculated to be 6.89, 5.24 and $3.27 \mathrm{eV}$, respectively. These results revealed that the reducibility of AA increased with the increase of the initial $\mathrm{pH}$ value (Table 1). Meanwhile, we also calculated the highest occupied molecular orbital - the lowest unoccupied molecular orbital (HOMO-LUMO) energy gaps of different AA protolytic forms, which were 8.03, 7.55 and $6.34 \mathrm{eV}$ for $\mathrm{C}_{6} \mathrm{H}_{8} \mathrm{O}_{6}, \mathrm{C}_{6} \mathrm{H}_{7} \mathrm{O}_{6}{ }^{-}$and $\mathrm{C}_{6} \mathrm{H}_{6} \mathrm{O}_{6}{ }^{2-}$, respectively. As a smaller HOMO-LUMO energy gap of a molecule corresponds to its lower reactivity, the activity of the different protolytic ascorbic acid was in the order of $\mathrm{C}_{6} \mathrm{H}_{6} \mathrm{O}_{6}{ }^{2-}>$ 
$\mathrm{C}_{6} \mathrm{H}_{7} \mathrm{O}_{6}{ }^{-}>\mathrm{C}_{6} \mathrm{H}_{8} \mathrm{O}_{6}$, consistent with their VIP value trend. In addition, the tendencies of VIP values and HOMO-LUMO energy gap values of different ascorbic acid protolytic forms were in agreement with their redox potentials (Table S3 in the Supporting Information) [25]. Furthermore, we measured the oxidation-reduction potentials (ORP) of different ascorbic acid protolytic forms and found that their ORP values decreased from $-23 \mathrm{mV}$ to $-348 \mathrm{mV}$ with increasing $\mathrm{pH}$ from 4 to 12 . Regarding that the smaller value of ORP corresponds to the higher reductive ability of ascorbic acid [36], our experimental observation was consistent with the theoretical calculation results based on the polarization models (Figure S6 in the Supporting Information). Therefore, we concluded that the higher atrazine degradation efficiency at $\mathrm{pH} 12$ was arisen from the higher reductive ability of $\mathrm{C}_{6} \mathrm{H}_{6} \mathrm{O}_{6}{ }^{2-}$.

Meanwhile, we also calculated the Gibbs free energies of different AA protolytic forms and their oxidized forms, atrazine and its reduced form (Table S4 in the Supporting Information), and then compared their redox potentials with the Gibbs free energies (Eq. 10).

$$
\mathrm{E}^{0}=\Delta \mathrm{G}^{0} / \mathrm{nF}
$$

It was found that the reduction potential $(0.24 \mathrm{~V})$ of atrazine was higher than those $(0.03 \mathrm{~V}$ for $\mathrm{H}_{2} \mathrm{~A}, 0.01$ for $\mathrm{HA}^{-}$and -0.01 for $\mathrm{A}^{2-}$ ) of different ascorbic acid protolytic forms, confirming that atrazine could be reduced by ascorbic acid theoretically. The values of Gibbs free energy changes $(\Delta \mathrm{G})$ of the reactions between AA and atrazine were all less than zero (Table S5 in the Supporting Information), suggesting that atrazine could be reduced by ascorbic acid under different $\mathrm{pH}$ conditions thermodynamically. In addition, the related kinetic process of the reaction between atrazine and AA was descripted in SI.

LC-MS analysis was also employed to investigate the degradation intermediates of AA during the atrazine degradation process (Figure S7 in the Supporting Information). The identified intermediates of AA at $\mathrm{pH} 4$ included dehygroascorbic acid (DHA, m/z = 173) and 2,3-diketogulonic acid (DKG, 
$\mathrm{m} / \mathrm{z}=191)$. While at $\mathrm{pH} 7$, only DHA was detected. As for $\mathrm{pH} 12$, DHA and 4,5,5,6-tetrahydroxy-2,3-diketohexanoic acid $(\mathrm{THDH}, \mathrm{m} / \mathrm{z}=207)$ were found. Among these intermediates of AA, DHA was the fully oxidized byproduct of AA and could be detected at three $\mathrm{pH}$ values. On the basis of these results, we also proposed a possible AA decomposition pathway at different $\mathrm{pH}$ values (Figure S8 in the Supporting Information).

It was found that AA could reduce carbon tetrachloride $\left(\mathrm{CCl}_{4}\right)$ with rate constant of 0.028 day $^{-1}$ in the presence of $10 \mathrm{mmol} \mathrm{L}^{-1}$ of $\mathrm{AA}\left([\mathrm{AA}]_{0} /\left[\mathrm{CCl}_{4}\right]_{0}=10 / 0.8\right)$ at $\mathrm{pH} 13$ [36]. After that, they also confirmed that alkaline ascorbic acid exhibited more effective activity on nitrobenzene (NB) reductive degradation with rate constant of 0.074 day $^{-1}$ in the presence of $50 \mathrm{mmol} \mathrm{L}^{-1}$ of AA $\left([\mathrm{AA}]_{0} /[\mathrm{NB}]_{0}=50 / 1\right)$ at $\mathrm{pH} 12[37]$. Moreover, AA could reduce $m e r-\left[\mathrm{Ru}^{\mathrm{III}}(\mathrm{pic})_{3}\right]$ complex $\left(\mathrm{pic}^{-}=\right.$ picolinato) to produce a red ruthenium(II) species in a wide $\mathrm{pH}$ range of $1.0-7.4$ with the reduced rate constant of $m e r$ - $\left[\mathrm{Ru}^{\mathrm{III}}(\text { pic) })_{3}\right]$ complex increasing from $0.445 \times 10^{-2} \mathrm{~s}^{-1}$ to $24.3 \mathrm{~s}^{-1}$ along with increasing $\mathrm{pH}$ values from 1.0 to 6.1 in the presence of $10 \mathrm{mmol} \mathrm{L}^{-1}$ of $\mathrm{AA}$ [28]. Moreover, several reports demonstrated that methylene blue could be reduced by AA under strongly acidic conditions [30-31]. The methylene blue reduction rate constant in the presence of AA was as high as $1.1 \times 10^{3}$ day $^{-1}$ at $\mathrm{pH} 0.2$ and increased with increasing the acidity. In this study, we found that atrazine could be degraded with $\mathrm{AA}$ in a wide $\mathrm{pH}$ range from 4 to 12 with higher reaction rate constants of 0.077 day $^{-1}$ at $\mathrm{pH} 4,0.017$ day $^{-1}$ at $\mathrm{pH} 7$ and 0.18 day $^{-1}$ at $\mathrm{pH} 12$, respectively. Interestingly, the atrazine degradation rate constant $\left(0.18\right.$ day $\left.^{-1}\right)$ at $\mathrm{pH} 12$ was 6.4 times that $\left(0.028\right.$ day $\left.^{-1}\right)$ of $\mathrm{CCl}_{4}$ degradation by $\mathrm{AA}$ at $\mathrm{pH}$ 13. These comparisons revealed that the AA induced organic pollutants reductive degradations were substrate dependent (Table S6).

\section{Conclusion.}

In this study, we compared the atrazine degradation efficiencies with ascorbic acid under different $\mathrm{pH}$ conditions and found that atrazine could be degraded by AA in a wide range of $\mathrm{pH}$ from 4 to 12 . 
We systematically compared the reductive ability of AA at different $\mathrm{pH}$ values and clarify the $\mathrm{pH}$ dependent reductive performance of AA. These results can shed light on the application of AA for the organic pollutant remediation. Furthermore, the atrazine degradation intermediates were qualitatively and quantitatively analyzed with different techniques. It is widely accepted that the toxicity of atrazine could be reduced through the replacement of chlorine with hydroxyl group. The appearance of atrazine dechlorination products in presence of $\mathrm{AA}$ at all the $\mathrm{pH}$ values suggests that AA is promising for the atrazine contaminated water remediation.

Acknowledgements: This work was supported by Natural Science Funds for The National Key Research and Development Program of China (2016YFA0203000), Distinguished Young Scholars (Grant 21425728), National Science Foundation of China (Grant 21177048, 21173093, 21477044, and 51472100), Key Project of Chinese National Programs for Research and Development (2016YFA0203002), Self-Determined Research Funds of CCNU from the Colleges' Basic Research and Operation of MOE (Grant CCNU16A02029, CCNU14Z01001, and CCNU14KFY002), and Excellent Doctorial Dissertation Cultivation Grant from Central China Normal University (Grant 2016YBZZ037).

\section{References}

[1] T.R. Roberts, D.H. Hudson, P.W. Lee, P.H. Nicholls, J.R. Plimmer, M.C. Roberts, L. Croucher, 1,3,5 Triazines: Atrazine. In Metabolic Pathways of Agrochemicals. Part 1. Herbicides and Plant Growth Regulators, Royal Society of Chemistry: Cambridge, UK, 1998.

[2] T.B. Hayes, A. Collins, M. Lee, M. Mendoza, N. Noriega, A.A. Stuart, A. Vonk, Hermaphroditic, demasculinized frogs after exposure to the herbicide atrazine at low ecologically relevant doses, Proc. Natl. Acad. Sci. 99 (2002) 5476-5480. 
[3] EPA. http://www.epa.gov/pesticides/factsheets/atrazine.htm

[4] European Commission. Decision No. 2455/2001/EC of the European Parliament and of the Council of 20 November 2001 establishing the List of Priority Substances in the Field of Water Policy and Amending Directive 2000/60/EC, 2001.

[5] T.E. Stoker, D.L. Guidici, S.C. Laws, R.L. Cooper, The effects of atrazine metabolites on puberty and thyroid function in the male Wistar rat, Toxicol. Sci. 67 (2002) 198-206.

[6] J.R. Rayner, R.R. Enoch, S.E. Fenton, Adverse effects of prenatal exposure to atrazine during a critical period of mammary gland growth, Toxicol. Sci. 87 (2005) 255-266.

[7] M.J. Ruiz, D. Marzin, Genotoxicity of six pesticides by salmonella mutagenicity test and SOS chromstest, Mutat. Res., Genet. Toxicol. Environ. Mutagen. 390 (1997) 245-255.

[8] M.M. El-Sheekha, H.M. Kotkatb, O.H.E. Hammouda, Effect of atrazine herbicide on growth, photosynthesis, protein synthesis, and fatty acid composition in the unicellular green alga Chlorella Kessleri, Ecotoxicol. Environ. Saf. 29 (1994) 349-358.

[9] G. Premazzi, R. Stecchi, Evaluation of the Impact of Atrazine on the Aquatic Environment; EUR12569 EN; Commission of the European Communities: Brussels, Belgium, 1990.

[10] M. Graymore, F. Stagnitti, G. Allinson, Impacts of atrazine in aquatic ecosystems. Environ. Int. 26 (2001) 483-495.

[11] K.R. Solomon, D.B. Baker, R.P. Richards, K.R. Dixon, S.J. Klaine, T.W. La Point, R.J. Kendall, C.P. Weisskopf, J.M. Giddings, J.P. Giesy, L.W. Hall, W.M. Williams, Ecological risk assessment of atrazine in North American surface waters, Environ. Toxicol. Chem. 15 (1996) 31-76.

[12] X. Liu, W.J. Li, L. Li, Y. Yang, L.G. Mao, Z. Penga, A label-free electrochemical immunosensor based on gold nanoparticles for direct detection of atrazine, Sensor. Actuat. B 191 (2014) 408-414.

[13] A. Caus, S. Vanderhaegen, L. Braeken, B. Van der Bruggen, Integrated nanofiltration cascades with low salt rejection for complete removal of pesticides in drinking water production, Desalination 
241 (2009) 111-117.

[14] EPA. https://nepis.epa.gov/Exe/

[15] M. Kabschkorbutowicz, K. Majewskanowak, Removal of atrazine from water by coagulation and adsorption, Oficyna Wydawnicza Politechniki Wrocławskiej, 2003.

[16] C. Gkementzoglou, O. Kotrotsiou, M. Koronaiou, Development of a Sandwich-type filtration unit packed with MIP nanoparticles for removal of atrazine from water sources, Chem. Eng. J. 287 (2015) 233-240.

[17] I.M. Verstraeten, E.M. Thurman, M.E. Lindsey, E.C. Lee, R.D. Smith, Changes in concentrations of triazine and acetamide herbicides by bank filtration, ozonation, and chlorination in public water supply, J. Hydrol. 266 (2002) 190-208.

[18] J.M. Arsuaga, M.J. Lopez-Munoz, J. Aguado, A. Sotto, Temperature, pH and concentration effects on retention and transport of organic pollutants across thin-film composite nanofiltration membranes, Desalination 221 (2008) 253-258.

[19] A.L. Ahmad, L.S. Tan, S.R.A. Shukor, Modeling of the retention of atrazine and dimethoate with nanofiltration, Chem. Eng. J. 147 (2009) 280-286.

[20] B. Schreiber, V. Schmalz, T. Brinkmann, E. Worch, The effect of water temperature on the adsorption equilibrium of dissolved organic matter and atrazine on granular activated carbon, Environ. Sci. Technol. 41 (2007) 6448-6453.

[21] C.L. Bianchi, C. Pirola, V. Ragaini, E. Selli, Mechanism and efficiency of atrazine degradation under combined oxidation processes, Appl. Catal., B 64 (2006) 131-138.

[22] W. Hua, E.R. Bennett, R.J. Letcher, Ozone treatment and the depletion of detectable pharmaceuticals and atrazine herbicide in drinking water sourced from the upper Detroit River, Ontario, Canada, Water Res. 40 (2006) 2259-2266.

[23] A.H. Meyer, H. Penning, M. Elsner, C and N isotope fractionation suggests similar mechanisms 
of microbial atrazine transformation despite involvement of different enzymes (AtzA and TrzN), Environ. Sci. Technol. 43 (2009) 8079-8085.

[24] T. Dombek, E. Dolan, J. Schultz, D. Klarup, Rapid reductive dechlorination of atrazine by zero-valent iron under acidic conditions. Environ. Pollut. 2001, 111, 21-27.

[25] M.B. Davies, D.A. Partridge, J. Austin, Vitamin C: Its Chemistry and Biochemistry, Royal Society of Chemistry: Cambridge, UK., 1991.

[26] M.P. Bradshaw, C. Barril, A.C. Clark, P.D. Prenzler, G.R. Scollary, Ascorbic acid: A review of its chemistry and reactivity in relation to a wine environment, Crit. Rev. Food Sci. Nutr. 51 (2011) 479-498.

[27] A.T. Stone, K.L. Godtfredsen, B. Deng, Sources and reactivity of reductants encountered in aquatic environments. In: Chemistry of Aquatic Systems: Local and Global Perspectives; Springer Netherlands, 1993 337-374.

[28] A. Katafias, O. Impert, P. Kita, J. Tenska, S. Koter, A. Kedziera, H. Rózycki, A. Bajek, M. Uzarska, R. Eldik, Kinetics and mechanism of the reduction of mer-tris-picolinatoruthenium(III) by L-ascorbic acid, Eur. J. Inorg. Chem. 15 (2014) 2529-2535.

[29] D.H. Macartney, N. Sutin, The oxidation of ascorbic acid by tris(2,2'-bipyridine) complexes of osmium(III), ruthenium(III) and nickel(III) in aqueous media: Applications of the Marcus cross-relation, Inorg. Chim. Acta. 74 (1983) 221-228.

[30] S. Mowry, P.J. Ogren, Kinetics of methylene blue reduction by ascorbic acid, J. Chem. Educ. 76 (1999) 970-973.

[31] T. Snehalatha, K.C. Rajanna, P.K. Saiprakash, Methylene blue-ascorbic acid, J. Chem. Educ. 74 (1997) 228-233.

[32] Y.H.P. Hsieh, Y.P. Hsieh, Kinetics of Fe(III) reduction by ascorbic acid in aqueous solutions, J. Agric. Food Chem. 48 (2000) 1569-1573. 
[33] D.H. Macartney, A. McAuley, The outer-sphere oxidation of ascorbic acid by the thioureapentacyanoferrate(III) ion, Can. J. Chem. 59 (1980) 132-137.

[34] N.H. Williams, J.K. Yandell, Outer-sphere electron-transfer reactions of ascorbate anions, Aust. J. Chem. 35 (1982) 1133-1144.

[35] A.I. Al-Ayash, M.J. Wilson, The mechanism of reduction of single-site redox proteins by ascorbic acid, Biochem. J. 177 (1979) 641-648.

[36] Y.T. Lin, C. Liang, Carbon tetrachloride degradation by alkaline ascorbic acid solution, Environ. Sci. Technol. 47 (2013) 3299-3307.

[37] C. Liang, Y.T. Lin, J.W. Shiu, Reduction of nitrobenzene with alkaline ascorbic acid: Kinetics and pathways, J. Hazard. Mater. 302 (2016) 137-143.

[38] D.M. Burman, H.G. Shertzer, A.P. Senft, T.P. Dalton, M.B. Genter, Antioxidant perturbations in the olfactory mucosa of alachlor-treated rats, Biochem. Pharmacol. 66 (2003) 1707-1715.

[39] M.J. Frisch, G.W. Trucks, H.B. Schlegel, G.E. Scuseria, M.A. Robb, J.R. Cheeseman, G. Scalmani, V. Barone, B. Mennucci, Gaussian 09, revision D.01, Gaussian, Inc., Wallingford, CT, 2009.

[40] S. Schenker, C. Schneider, S.B. Tsogoeva, T. Clark, Assessment of popular DFT and semiempirical molecular orbital techniques for calculating relative transition state energies and kinetic product distributions in enantioselective organocatalytic reactions, J. Chem. Theory Comput. 10 (2010) 7-11.

[41] E. Cances, B. Mennucci, J. Tomasi, A new integral equation formalism for the polarizable continuum model: Theoretical background and applications to isotropic and anisotropic dielectrics, J. Chem. Phys. 107 (1997) 3032-3041.

[42] C. Chen, S.G. Yang, Y.P. Guo, C. Sun, C.G. Gu, B. Xu, Photolytic destruction of endocrine disruptor atrazine in aqueous solution under UV irradiation: Products and pathways. J Hazard. Mater. 
172 (2009) 675-684.

[43] B. Bslci, N. Oturan, R. Cherrier, M.A. Oturan, Degradation of atrazine in aqueous medium by electrocatalytically generated hydroxyl radicals electrocatalytically generated hydroxyl radicals. A kinetic and mechanistic study, Water Res. 43 (2009) 1924-1934.

[44] G.W. Stratton, Effects of the herbicide atrazine and its degradation products, alone and in combination, on phototrophic microorganisms, Arch. Environ. Contam. Toxicol. 13 (1984) 35-42.

[45] A.B. Baranda, A. Barranco, I.M. de Marañón, Fast atrazine photodegradation in water by pulsed light technology, Water Res. 46 (2012) 669-678.

[46] M. Hincapié, M.I. Maldonado, I. Oller, W. Gernjak, J.A. Sánchez-Pérez, M.M. Ballesteros, S. Malato, Solar photocatalytic degradation and detoxification of EU priority substances, Catal. Today 101 (2005) 203-210.

[47] M.J. López-Muñoz, J. Aguado, A. Revilla, Photocatalytic removal of s-triazines:evaluation of operational parameters, Catal. Today 161 (2011) 153-162.

[48] T.K. Ralebitso, E. Senior, H.W. Van Verseveld, Microbial aspects of atrazine degradation in natural environment, Biodegradation 13 (2002) 11-19.

[49] J.O. Howell, J.M. Goncalves, C. Amatore, L. Klasinc, R.M. Wightman, J.K. Kochi, Electron transfer from aromatic hydrocarbons and their $\pi$-complexes with metals. Comparison of the standard oxidation potentials and vertical ionization potentials, J. Am. Chem. Soc. 106 (1984) 3968-3976. 


\section{Figure Captions}
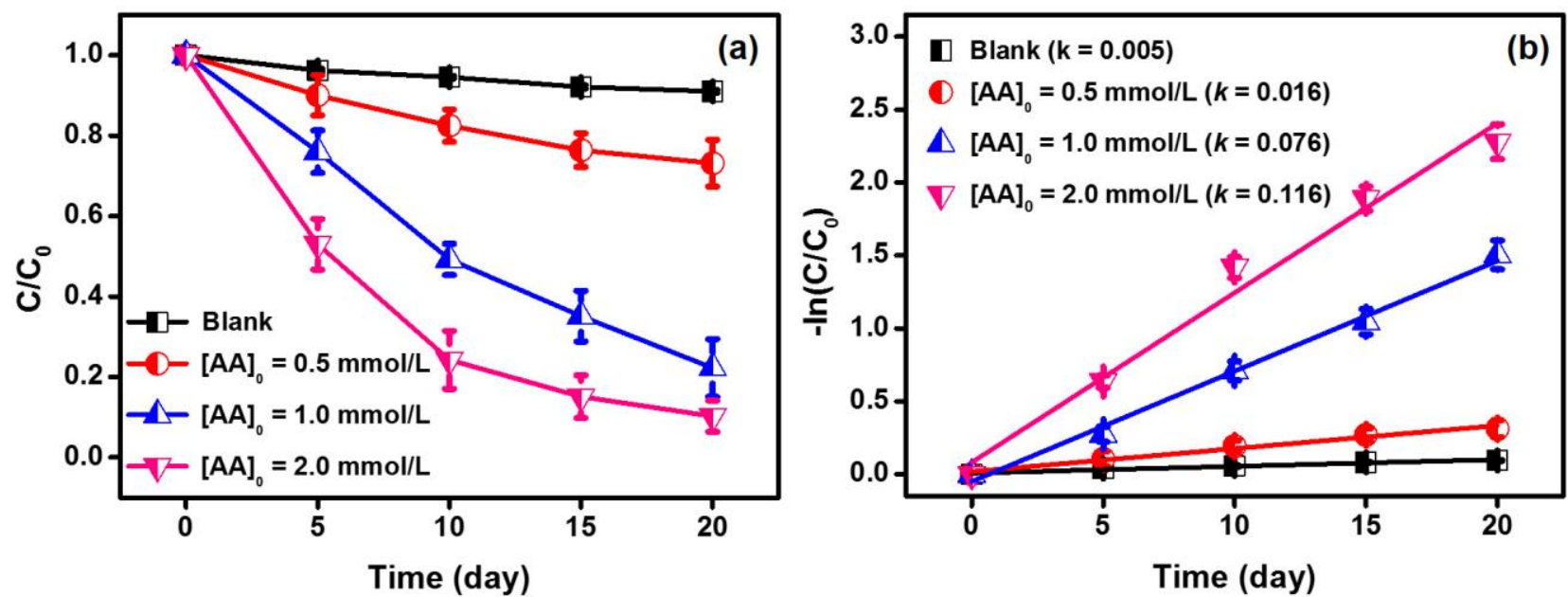

Figure 1. (a) Time profiles of the atrazine degradation with different AA concentrations. (b) Plots of $-\ln \left(\mathrm{C} / \mathrm{C}_{0}\right)$ versus time for the atrazine degradation with different AA concentrations. Time profiles of atrazine anaerobic degradation with different AA concentrations. The initial concentration of atrazine was $1.0 \times 10^{-5} \mathrm{~mol} / \mathrm{L}$; the initial concentrations of AA were $0.5 \times 10^{-3}, 1.0 \times 10^{-3}, 0.2 \times 10^{-3} \mathrm{~mol} / \mathrm{L}$, respectively; all the initial $\mathrm{pH}$ values were about 4.

(a)
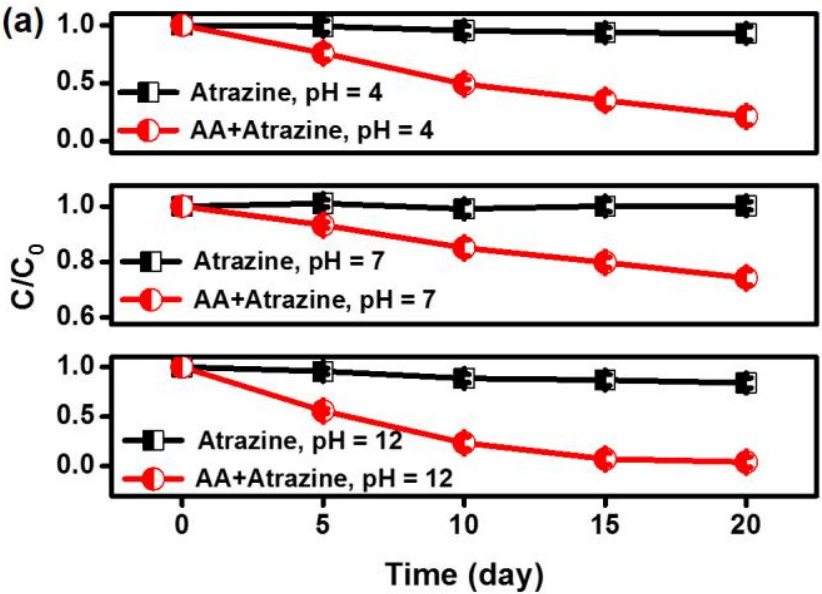

(b) 2 Atrazine, $\mathrm{pH}=4(k=0.005)$
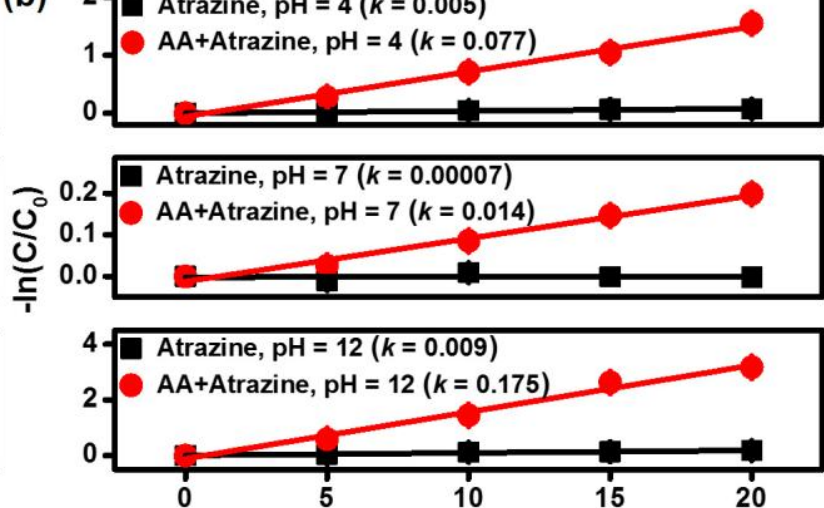

Time (day)

Figure 2. (a) Time profiles of atrazine anaerobic degradation in the presence of AA at different initial $\mathrm{pH}$ values; (b) Plots of $-\ln \left(\mathrm{C} / \mathrm{C}_{0}\right)$ versus time for the degradation of atrazine in the presence of AA. The initial concentrations of atrazine and AA were $1.0 \times 10^{-5}$ and $1 \times 10^{-3} \mathrm{~mol} / \mathrm{L}$, respectively. 


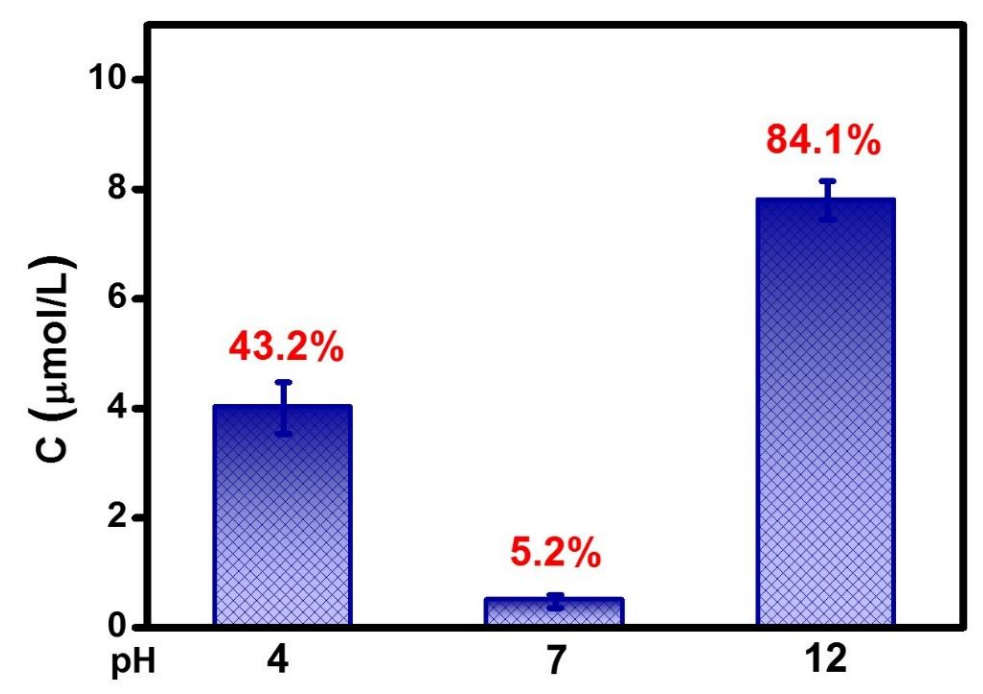

Figure 3. Concentration change of $\mathrm{Cl}^{-}$as a function of reaction time during the atrazine anaerobic degradation at different initial $\mathrm{pH}$ values.
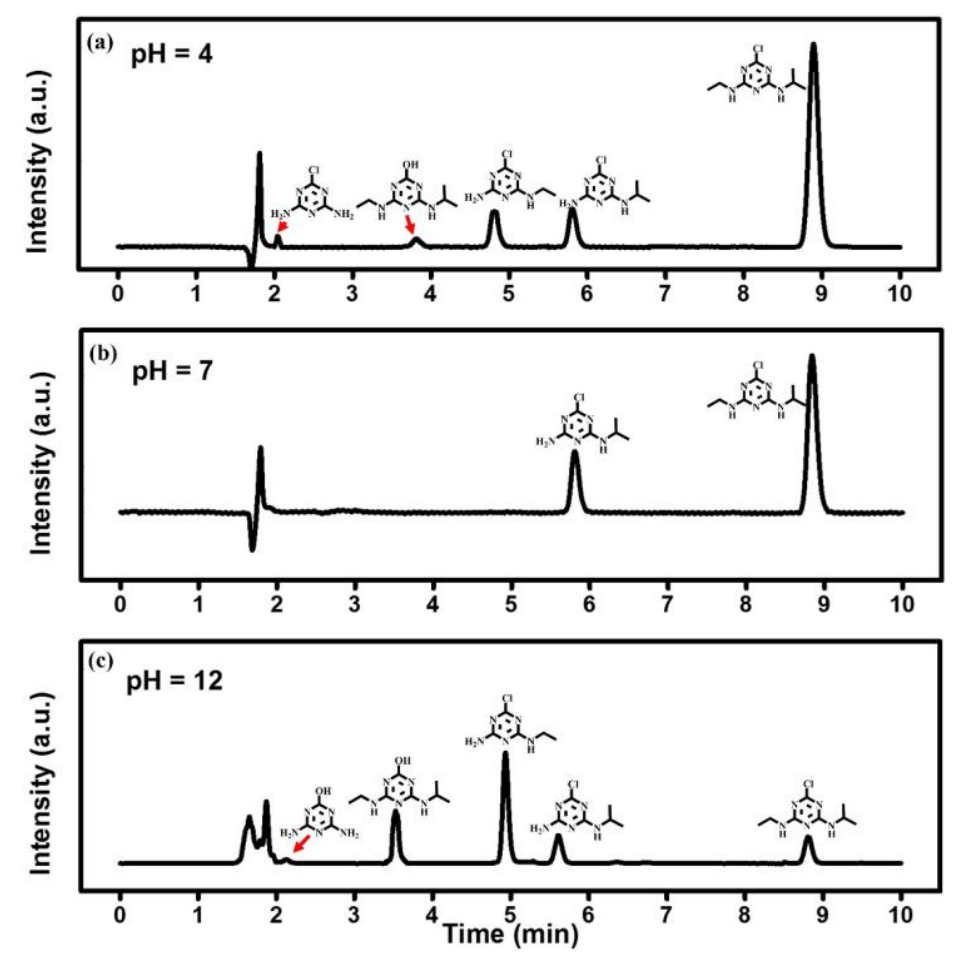

Figure 4. HPLC spectra of the intermediates during atrazine anaerobic degradation in the presence of AA at different initial $\mathrm{pH}$ values after 20 days: (a) $\mathrm{pH}=4$; (b) $\mathrm{pH}=7$; (c) $\mathrm{pH}=12$. 

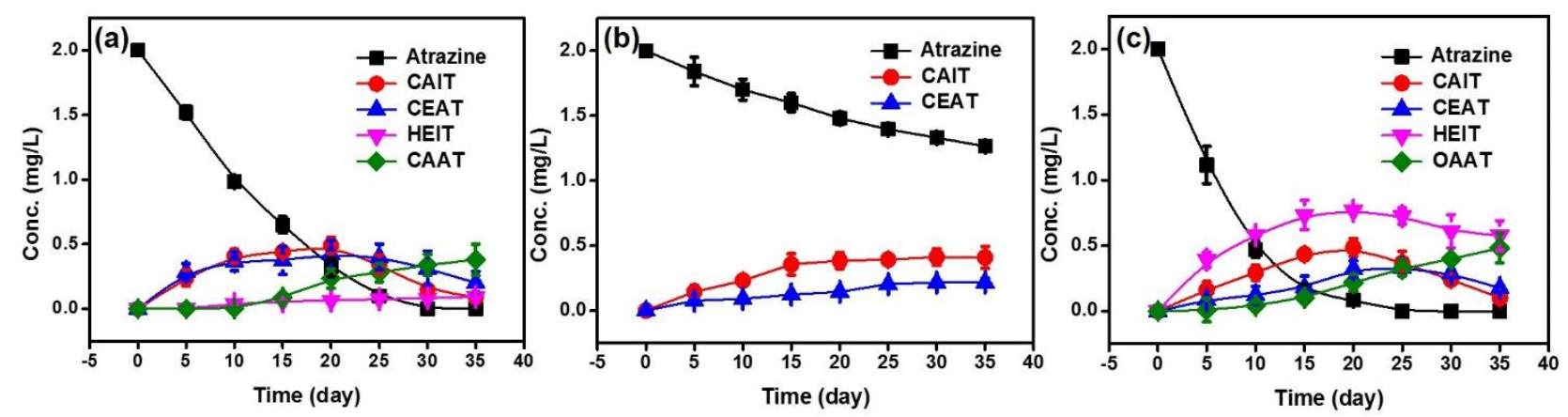

Figure 5. Concentration changes of the intermediate products of atrazine degraded in the presence of AA at different initial $\mathrm{pH}$ values: (a) $\mathrm{pH}=4$; (b) $\mathrm{pH}=7$; (c) $\mathrm{pH}=12$.

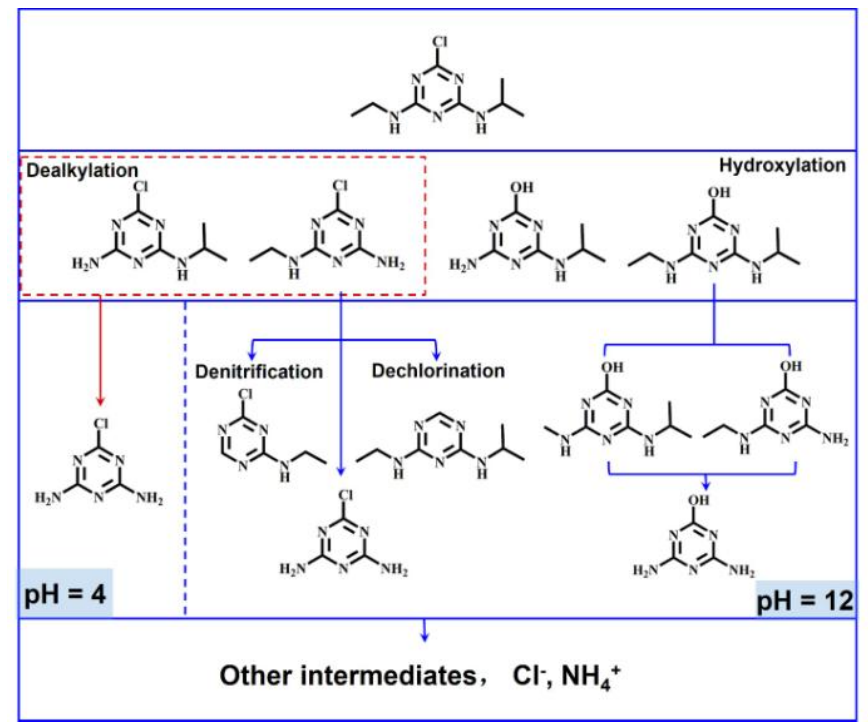

Figure 6. The scheme of atrazine degradation in the presence of AA at different initial pH values.

Table 1. The vertical ionization potentials (VIP) and LUMO-HOMO energy gaps of different protolytic ascorbic acid calculated using the M062X functional with the TZVP basis in solvent (water).

\begin{tabular}{cccc}
\hline & $\mathbf{H}_{2} \mathbf{A}$ & $\mathbf{H A}^{-}$ & $\mathbf{A}^{2-}$ \\
\hline VIP $(\mathbf{e V})$ & 6.89 & 5.24 & 3.27 \\
HOMO-LUMO $(\mathbf{e V})$ & 8.04 & 7.55 & 6.34 \\
\hline
\end{tabular}




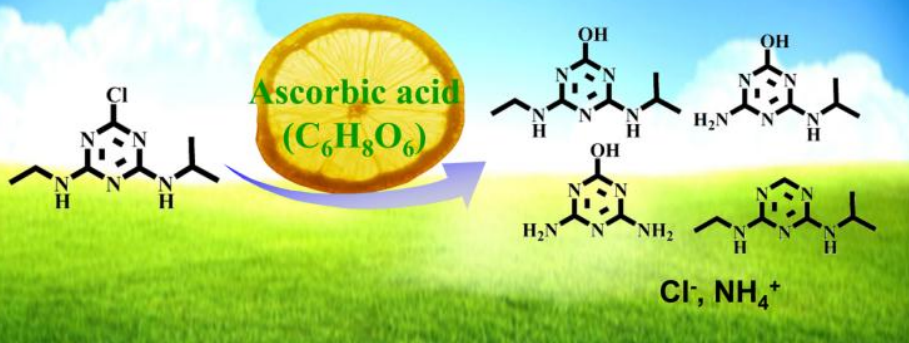

